\title{
拠点外空間での保育に着目した \\ 小規模保育拠点運営の実態と保育者による都市環境評価 京都・昼間里親と大阪・保育所分園制度を対象として \\ STUDY ON THE EVALUATION OF URBAN ENVIRONMENT AS CHILD NURTURING ENVIRONMENT BY STAFF \\ OF SMALL BASES FOR CHILD-CARE
}

Focused on the daytime-guardian system (Kyoto) and the branched day-nursery system (Osaka)

\section{山田あすか*}

\section{Asuka YAMADA}

\begin{abstract}
This paper aimed to research about the small bases for child-care that used the environment of the cities such as parks for their childcare.

First, design of institutional arrangements and actual situation of administration were arranged targeted the two systems, daytime-guardian system (Kyoto) and the branched day-nursery system (Osaka).

Next, Evaluation comments to the environmental element of the urban space by the staff of bases were collected when the staff and children used the urban space as child nurturing space with Caption Evaluation Method.

And, some matters pursued in the urban environment as the place of the childcare were derived by analysis and consideration.
\end{abstract}

Keywords : small bases for child-care, group home, child nurturing environment, evaluation of urban environment, caption evaluation method 小規模保育拠点，保育環境，都市環境評価，キャプション評価法

\section{1. 背景と目的}

\section{1 社会的背景}

我が国では, 少子・超高齢社会, 人口減少社会の到来に鑑み, 労 働人口を保ちつつ世代の安定的な推移を図るため, 子育てと就労の 両立を支援する施策が求められている，現実には，共働き・一人親 世帯の増加や核家族化の進行などとともに增大・多様化する保育 ニーズは充足されていない。このため特に都市部で年少児を中心に 待機児童問題が顥在化して久しく, 定員を超過しての児童の受け入 れや保育所の増設などの対策が行われている. しかし, 保育サービ スの供給が潜在需要を顕在化する構造もあって待機児童は解消して おらず, 就労支援の観点からも早急な対策が必要とされている ${ }^{11}$.

待機児童がいる一方で少子化傾向があることも保育所の増設を困 難にしている，従来の大規模保育施設を建設する手法では資金や土 地の取得，建設に時間を要するため，保育ニーズに直ちに対応しに くく,また将来的に保育ニーズが滅少した場合に施設が余剩する可 能性がある。そこで自治体によっては, 家庭保育福祉員 (家庭福祉員, 保育ママ) や保育所分園, 自治体独自の認証・認定保育施設などの 制度で，住宅や既存建物を利用した小規模な保育施設を設けている.

このような小規模保育拠点を地域に多数配する保育サービス配固 手法は, 従来の大規模保育施設建設の手法に比べて整備が容易かつ 安価で, その時々の地域の保育二ーズに応じて保育の提供を迅速に 開始でき，かつ将来の保育ニーズの変動に対応しやすいという利点
がある，一方で多くの小規模保育拠点では園庭などの外部保育環境 を独自にもたないため, 室内だけの保育ではこどもに適切な発達刺 激を保障することが難しいという照念もある.このためこうした保 育拠点による保育サーピス提供を行うためには, 公園などの都市環 境が周囲に適切に整備されていることが必須の条件となる゙注1．

\section{2 理論的背景}

保育を提供する小規模な施設や保育の環境についての既往研究に は, 家庭福祉員当事者らの視点に基づく田島・伊志嶺らの家庭福祉 員による保育制度の現状や課題に関する研究 ${ }^{2)}$, 地域の子育て支援 施設の利用実態に関する研究 ${ }^{3)}$ や北浦らの夜間保育所に関する研 究, 赤木らの駅前保育施設に関する研究などがある ${ }^{4) ~ 51}$. 特に田 島らの研究 ${ }^{2)}$ では, 家庭福祉員制度は家庭的な密度の瀑い保育や保 育時間に融通が利くことなどが利点である一方, 福祉員の労働環境 や保育の質の保障に課題があるとし, 認可保育所との連携や支援七 ンターの設立を提言するなど保育の現場に根ざした価值ある指摘が なされている．しかしこれらの研究では，小規模な保育拠点での保 有で活用され保育や発達の保障を支えるスペースである公園などの 都市環境については充分に論じられていない. 松橋・谷口らの横浜 市の保育施設を対象とした研究では, 公園や商店街, 地域施設など を地域の資源として園外での保育が日常的に行われ，施設内部だけ では保障しきれない子供たちの様々な体験の場として活用されてい ることを報告している ${ }^{6) \sim 8)}$. また施設外部の屋外保育空間について,

\footnotetext{
本稿は、木村拓真氏(立命館大学理工学部建築都市デザイン学科卒業，2008年 3 月)との咕同研究による成果を参照し、まとめられたものです。

“東京電機大学未来科学部建築学科 准教授 ·博士(工学) Assoc. Prof., Department of Architecture, School of Science and Technology for Future Life, Tokyo Denki University, Dr. Eng.
} 
小池ら ${ }^{9)}$ は, 小規模保育施設による公園や住宅周辺のオープンスペー ス等の都市環境利用の実態をこどもの活動に焦点をあてて報告して いる.これらの研究では保育施設を拠点に周辺地域が保育空間とし て活用されていることが明らかにされ，その重要性が示唆されてい る.しかし、こうした施設外の屋外空間を利用する際に保育者がど のような視点で環境を捉え, 保育空間としての安全性や遊び場とし ての価値を見いだしているのかは充分に論じられていない. また， 具体的にどのようなことがらが課題，あるいは保育に役立つ環境要 因だと認識されているかについては充分に整理されていない.

\section{3 研究の目的}

以上より本稿では, 公園などの都市の環境を保育の場とする小規 模保育拠点に着目する。この小規模保育拠点での保育の提供を支え る環境としての都市空間整備に資する知見を得るため, まず対象と する小規模保育拠点制度の設定上，環境面でどのような配虑をして いるかを整理する．さらに，小規模保育拠点の保育者が拠点外の都 市空間を保育の場として利用する際に, 都市空間の環境要素に対し てどのような評価をしているかを明らかにすることを目的とする. この際，評価の内容を具体的に捉える調查法を採用し，保育者によ る都市空間での保育現場での環境評価の実態を把握し, 分析の対象 とする. また, 今後の環境整備への展開を考慮し, 所轄の自治体へ の意識調査を併せて行うものとする.

なお本稿は，仕事と子育ての両立の困難さや少子化などの子育て に関する問題を都市構造非2) の観点から考究する研究の一環である.

\section{4 研究の対象}

小規模保育拠点としては, 家庭保育福祉員（定員 $2 \sim 3$ 人, 5 人 など）功認可保育所の分園, 自治体独自の認証·認定保育施設（東 京都認証保育所の定員 $20 \sim 120$ 人など）が挙げられ，それぞれ保 育拠点の規模や運営の仕組みが異なる。本研究では, 将来的にはこ れら種々の小規模保育拠点から都市空間を保育の環境として利用す る際の環境への意識や評価，必要とされる空間整備を捉えていく. まず本稿では, 京都市の昼間里親制度を主たる調査対象に設定する. この制度は，わが国における自治体主導による家庭的で小規模な保 育拠点の先駆けであり,現在国が推進している「家庭的保育事業」(家 庭保育福祉員, 保育ママ,など）制度のモデルともなった事業である. また，同保育事業の規模設定や運営の仕組みによる特徵を考察する ため, 上記の小規模保育拠点のうち, 運営の規模や仕組みが認可保 育所の形態に最も近い保育所分園制度 (大阪市) を比較対象とした.

\section{2. 研究の方法}

\section{1 調査対象}

京都市での対象保育拠点は, 京都市にある全 32 筒所の保育拠点 のうち, 調査許諾を得られた 8 拠点である. 大阪での比較調査対象 とした保育拠点は, 保育所分園のうち調査許諾が得られ, かつ類似 した形態の運営事例が多い 2 拠点である. 対象保育拠点の一覧は表 3 の通りで，立地する地域はいずれも京都市，大阪市の都心部に位 圈し，住宅系用途地域と商業／工業系用途地域が混在している.

\section{2 調査概要}

調査対象とした小規模保育拠点制度の概要や運営上の課題, 都市 環境との関わり等を概観するため, 自治体へのヒアリング調査を 行った (表 1). 各保育拠点での調査内容は, 1 : 運営概要と外出状
況についてのヒアリング調査, II : 終日の活動の様子についての観 察調查, III：キャプション評価法 ${ }^{10,11)}$ による都市環境についての

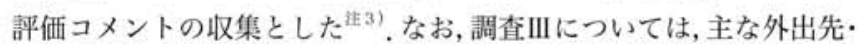
外出ルートをヒアリングし，それが複数あると回答した事例のうち， 調查協力を得られた KA，KBは，それぞれ2ルートを調べた非）.

\section{3. 自治体へのヒアリングによる小規模保育拠点制度の概要}

調査対象とした小規模保育拠点事業の, 自治体の保育行政全体の なかでの位置づけを得るため, 表 2 に自治体へのヒアリングによる 自治体圈の保育行政の状況と小規模保育拠点の概要を整理した。

\section{1 調査対象自治体の保育行政の概要}

1 ) 京都市 京都市では, 市域全体での児童数全体は減少の傾向 だが，一部地域では住宅の建設などによる人口流入によって就学前 児童数が増えている. また女性の就労率の上昇や子育て世代での核 家族の増加が影響して保育ニーズが増し，特に $0 \sim 1$ 歳での待機児 童が多い, 京都市の保育所の 9 割は民設民営だが, 近年人口流入が 進む中心地では用地取得等の問題があり新設は困難である。このた め, 保育所新設だけでなく既存建物の増改築や定員の緩和, 昼間里 親制度によって受け入れ定員を増やす方向で施策を進めている.

2）大阪市 大阪市では, 女性の就労率の上昇や子育て世代の転 入に伴い保育ニーズが増加し続けている，慢性化した待機児童問題 の解消のため, 財政や将来の保育ニーズの変動も見越して, 新規の 保育所建設だけでなく保育所分園や認定こと゚も園（幼稚園空き教室 と人材の有効活用), 保育ママ制度を組み合わせた施策を実施してい る. 保育ママ制度は立ち上げたばかりで, また法人への委託による 制度設計の影響むあってなり手がなく（表 2 , 保育料と委託), 事業 の展開は進んでいない, 一方, 保育所分園制度は整備が進んでいる。

\section{2 調査対象とする拠点事業の概要と役割}

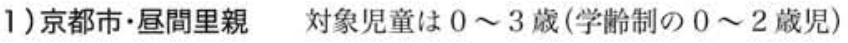

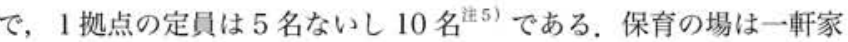
を原則としており，小規模で家庭的な保育が行われる．このため保 護者が低年軨児のうちは小規模な環境で育てたいと考えている，大 規模な園には発達や性格の面でなじみにくい, などの事例で就園相 談がある. 歴史がある制度のため地域に根ざして運営され, 地域と の日常的で自然な交流がある. 保育規模は国の家庭的保育事業のガ

\section{表 1 調查概要}

1: 運営概要と外出状況についてのヒアリング雕育

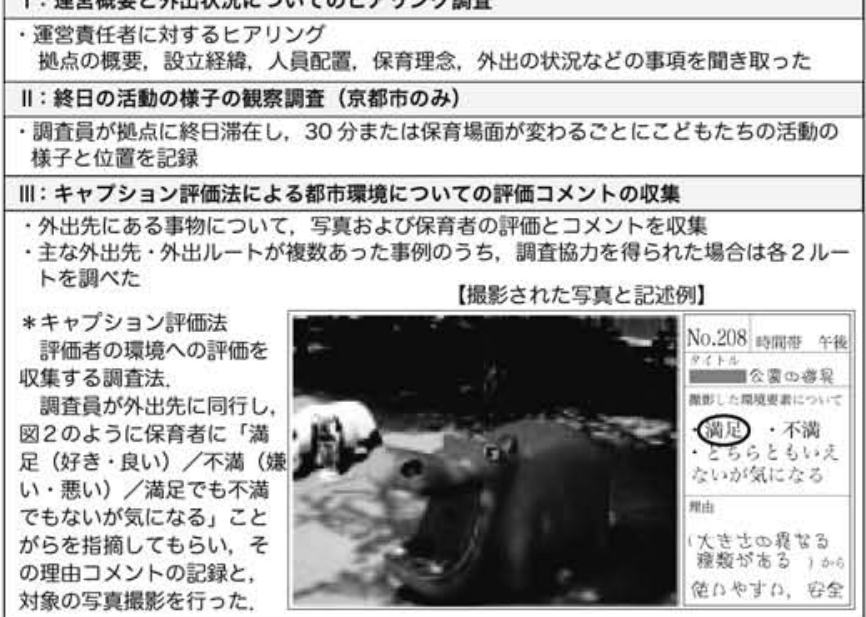


イドラインに比べて大きいが，少子化を踏まえてこどもに集団体験 を保障する, きょうだいで就園しやすい, また経営・運営の安定の 面からちょうど良い人数規模だとの考えが聞かれた. 現在の拠点数 は32で, 㹡充を目指しているが予算の問題で整備が難航している. 2）大阪市・保育所分園 保育所分園は, 認可保育所 (本園) と 提携する園で，定員は 30 名まで．対象児童は認可上学䑪の $0 \sim 5$ 歳児だが, 実際はおおむね学歯 $0 \sim 2$ 歳児が利用している. 大規模 な保育所にこども自身の発達や性格などの理由でなじめないケース での就園希望もあり, 従来に比べて小規模で家庭的な保育環境が評 価されている. コスト, 即効性, 定只増のバランスという保育行政 施策にも, 保護者の保育所選びにも選択肢があることが大切との考 えであり，保育ママなどさらに小規模な拠点と併せて整備を進める 方針である. 拠点数は現在 72 で, さらに数を增やしたいが母体と なる保育所 (法人) からの応募がなく, 行政からの依頼を重ねている.

\section{3 行政による保育環境としての都市環境の認識}

小規模保育拠点の整備にあたり，認定の条件には昼間里親，保育 所分園とも，拠点に屋外で遊べる場所をもつか，拠点の近隣に外出 保育の場所があることが要件にある。しかし群細な条件はなく, 例
えば公園への距離や時間距離, 経路などの規定はない, 外出先の状 況についての認識を尋ねると, いずれも公園, 寺社などが多いため これ以上の都市環境の整備などの必要はないと認識していた。

\section{4. 保育拠点へのヒアリングによる小規模保育拠点の利点と課題}

\section{1 保育対象について}

調査対象とした小規模保育拠点の運営者へのヒアリングの結果を 表 3 にまとめた。この結果から小規模保育拠点での保育対象につい ては, 昼間里親・保育所分園とも現在の主たる利用児である学䏩の $0 \sim 2$ 藏児までと考える運営者が大半であり, それ以上の年粭の場 合は発達に伴う行動範囲の拡大やこども集団との関わりにおいて適 切な発達環境を保障しかねるとの回答であった. 同時に, 現在の面 積基準などがいまの保育対象のこどもにとって狭いという意見もな く, 現在の保育対象への環境としては充足されているといえる.

\section{2 小規模保育拠点事業の利点}

小規模保育拠点の利点として指摘されてきた, 家庭的な保育環境 やなじみやすさ, 保育者との信頼関係の築きやすさ ${ }^{2)}$ は, 昼間里親 でも同様に挙げられ，また異年榆児が混在するため低年䑪児の世話

\section{表2 自治体へのヒアリングによる小規模保育拠点事業の概況}

\begin{tabular}{|c|c|c|}
\hline & 質間事項 & （虽間里䚂） \\
\hline & & $\begin{array}{l}\text { 京都市は学生が多くもともと平均世带人口が少ない，このため，明らかな世带人口 } \\
\text { 滅少傾向は見られなが核家族率はがっている.女性の就労率も年々上昇傾向. }\end{array}$ \\
\hline & 児童数 (出 & $\begin{array}{l}\text { 出生率は京都市全体として上昇傾向だが，児童数自体は滅少の傾向。西京区，伏見 } \\
\text { 区など京都市の西·南部では住宅建設によるる人流入があり急激な変化が見られる }\end{array}$ \\
\hline & $\begin{array}{l}\text { 保育ニース } \\
\text { と待機児童 } \\
\text { 数 }\end{array}$ & 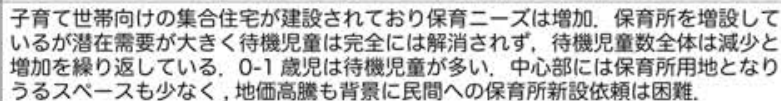 \\
\hline & $\begin{array}{l}\text { 保育行政の } \\
\text { 方針 }\end{array}$ & 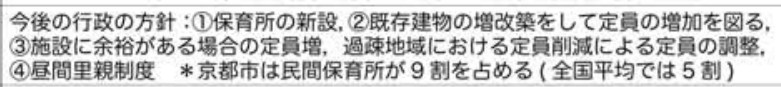 \\
\hline & $\begin{array}{l}\text { 小規模保育 } \\
\text { 挂点の状況 }\end{array}$ & 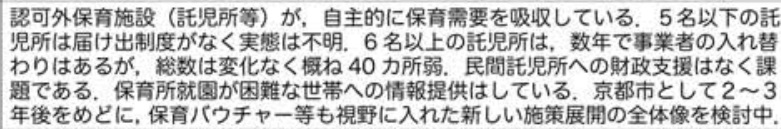 \\
\hline & $\begin{array}{l}\text { 自治体とし } \\
\text { ての小規模 } \\
\text { 保育挂点事 } \\
\text { 業への取組 }\end{array}$ & 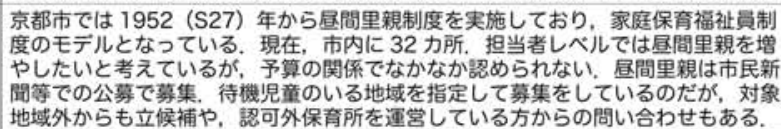 \\
\hline & 制度の概要 & 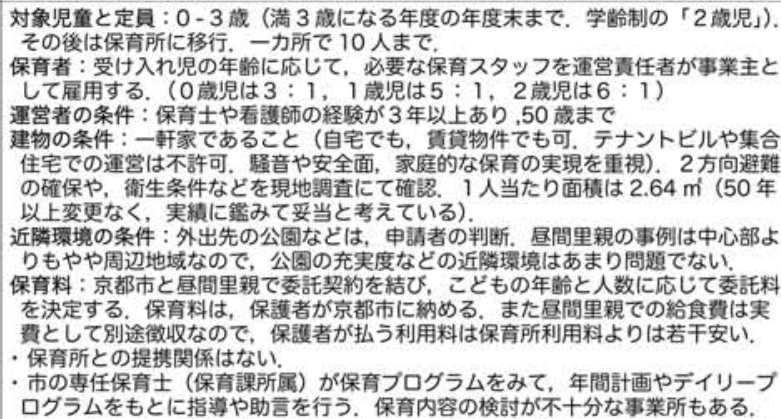 \\
\hline & $\begin{array}{l}\text { 事策の狙い } \\
\text { と利点. 課 } \\
\text { 題点 }\end{array}$ & 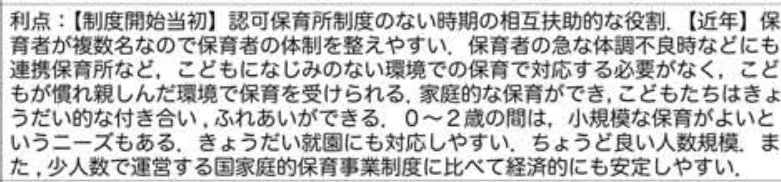 \\
\hline & $\begin{array}{l}\text { 地域 (保靲 } \\
\text { 者)の受け } \\
\text { 止め方 }\end{array}$ & 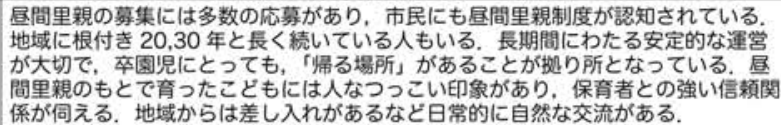 \\
\hline & $\begin{array}{l}\text { 制度推進の } \\
\text { 取組、広報 }\end{array}$ & 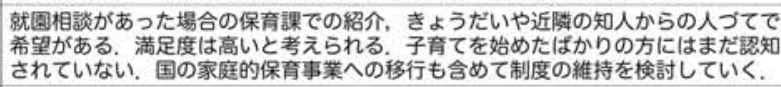 \\
\hline & $\begin{array}{l}\text { 制度運営上 } \\
\text { の困難 }\end{array}$ & 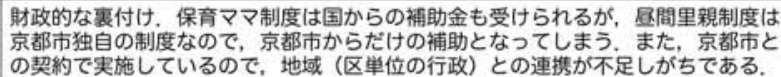 \\
\hline
\end{tabular}

女性の就労率は経済動向によらず増加傾向，核家族率については，もともと地方か らの転入が多く従来から核家族が多い地域であり、変化はあまり見られない,

児童数は減少.しかし集合住宅を含む大規模再開発で人口が流入しており,保育二ー スが増か力。保育所の定員を增やしているが潜在需要もあり待機児童が解消されない, 周辺自治体と比べても待機児童は 700 人近くと多い，保育所定員増によって，待

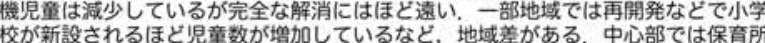
の新設は用地やコストの観点から難しい.

(1)民設民営での新設 (本園), (2)分園, (3)幼保連擭型の認定こども園を 2010 年まで に低コストで充実させる (ニースの将来的変動を見込んで). 認定こども園は大服 府と連携して整備の方針だが, 現状では市内 0 力所, 府内 2 力所。

市内には認可外保育施設が多く、事業者の入れ替わりはあるが届け出を受けて登録 しているものて 120 カ所弱. 多样な勤務体系などを背景として, 24 時間閒所のヘ ヒーホテル (夜間保育所) や事業所内保育施設も含まれる。保育者数や資格, 保育 室面積, 保育室設置階数などの条件に基づき, 立ち入り詢査を行って必要がある場 合には改善指導を行っている (基準を満たすものは21 年内で半数). 保育所の分園制度と, 保育ママ制度を同時平行で实施・推進している。

現在 72 力所. コストが低く即効性があり 当初 H19-21 の3 年間の計画だったが継

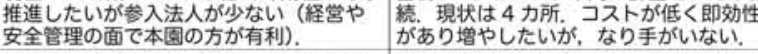

対象児童と定員：0〜 5歲，30名まで 実際には学齡の 0 2 盛児が大半。

保育者：资格, 配置は認可保育所に同し に同じ (大阪市の基準 : $5 \mathrm{~m} / 0$ 歲児 几同じ (大阪市の基準: $5 \mathrm{~m} / 0$ 歲児 1名)。制度設計当初 $(\mathrm{H} 13)$ は駅前な ど交通アクセスの要所が条件だったが, 貨紏が高く環境が悪いため, 駅近くど いう要件は撤回した。保育所に相巵し くない建物の改修の場合は許可しない。 保育料と委託 : 保育料は認可保育所に同 し. 大阪市から本園に補助金が降りる。 本園との連携：給食は本園から運ふ，分 園に園庭がなため本園で遊ひ，分園 と本園のこどもの交流がある埸合もあ る、 7 キロ離れて立地するケースもあ り, 本图との連撕体制はまちまち。

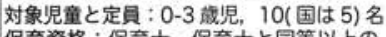
保育资格：保育士，保育士と同等以上の 傤及ひ経験の保持者. 主たる保育者 十蛹的者1, の組み合わせを 2 組で運 宫. (国は児童 3 : 保育者 1 、補助員か いる場合は 5 名まで保育可) 建物等の条件 :(1)保育専用室, (2)室の面䅡 が 9.9 m以上, 3 人を超える場合は 4 人目からの児童 1 人あたり 3.3 m加

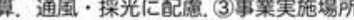
の敷地内に幼児の遊戲等に適する広さ の庭 これに代わるべき付近にある公 图等の場所), (4)衛生、災害への配盧 保育料と秀䚽：運常は，福祉法人にすへ て委託、賣貸物件を月額 10 万円を

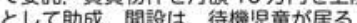

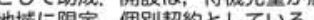

利点：短期間整備，(駅前立地）利便性, 少人数の低年鮯児に対する1クッション 将来への対応, 少人数制に対するニーズ. の役割を期待. 少人数保育の 1 つ選択 課題点: 園庭の不備, 給食 (キッチン設 肢. 分園よりも即効性がある. 保育ママ 備を持たないケースや、人件費). 市と はハード的に分園に比べて比較的制約 しても, 運営助成金に加えて本圈と分園 (面積、消防, 耐震など) が少ない, のバイプ役への人件費を補助. 民間に人 可外の家庭保育という位置づけ. 保育所 的余裕や補助の不满もあり希望がない, との連携が必須で個人ベースではない,

「今いっている保着所になじめない,などの問い合わせがある. 保育ママ, 分園が ある区の担当部署には知識があるが, その他の区ではあまり周知されていない（大 阪市に問い合わせが回送される)。制度は認知され始めた段階という印象、小規模 な保育や家庭的な保育のニーズは一定数ある。いまは本園と分園の連携が行われ いる段階だが、制度が定着すれば今後地域の施設などとの連擭が進むと考える。 設置や推進に向けて基準などのハードルを低くすることを検討している．また，コ スト面 (補助が不十分) に課題があり, 解決策を模索している. 就園相談があれば 情報提供 $/$ 斡旋をしている。選択肢を用意することが重要と考えている。

保育所分圈, 保育ママとも推進していこうとしているのになり手がいないこと. 人 的余裕がないこと, 照可保育所運営とのコスト面でのバランスが不十分なことが原 因と思われ，適切な助成を検討している段陸。 
を介して弱い者への思いやりの心が㕕まれることが挙げられた。一 方保育所分園では, 認可保育所に比べ小規模であるための利点は挙 げられず，駅に近いなど保護者にとっての利便性が指摘された。保 育所分園では各年榆児 10 人前後で， 2 拠点とも年龄ごとにクラスを 編成している．このような人数規模の違いがもたらす運営状況の違 いが, こどもにとって小規模な保育環境であることの価值について の考えに差異が生じる要因となっているのではないかと考える.

\section{3 外出保育の状況と拠点外の場所や環境への要望}

1 ）外出保育の頻度と内容 外出保育は, KG を除くすべての拠 点でほぼ毎日, いずれも 1 時間〜 1 時間半程度行うとの回答で, 既 往研究での指摘 ${ }^{6)}$-9) と同様, 外出保育は日常の保方の一環である. 小雨程度ならば外出する拠点もある $(\mathrm{KC}, \mathrm{KD})$. 外出の範囲は, 昼 間里親では $15 \sim 30$ 分以内, 保育所分園では $5 \sim 15$ 分の場所で, 昼間里親は保育所分園よりも時間距離による行動範囲が広い. 外出 先には近隣の公園, 少し離れた大きな公園, 寺社境内, が挙げられた. 保育の内容には電車の見学, 虫やドングリなどの採集遊び, 公園で の遊具遊びなどが挙げられ, 昼間里親と保充所分園で差異はない.
2) 都市環境への要望外出保育に際しての地域の環境への要㕵 として, 緑地や自然 $(\mathrm{KB}, \mathrm{OB})$, 雨天時に遊べ室内型の遊び場所 $(\mathrm{KA}, \mathrm{KH})$, 拠点近くの公園 $(\mathrm{KC}, \mathrm{KD}, \mathrm{KF}, \mathrm{KG}, \mathrm{OA})$, 安全·快 適な道空間 $(\mathrm{KC}, \mathrm{KD}, \mathrm{OA}, \mathrm{OB})$ が挙げられた。この結果には昼 間里親と保育所分園で差異はない.これらの小規模保育拠点ではい ずれも, 拠点内部のみの保育でこどもへの適切な発達環境を保障す ることは難しく, 外出しやすい環境を整えることが必要だと確認で きる、また自治体へのヒアリング (表 2 ) では, 自治体としては京 都市・大阪市とも公園や寺社が地域に多くあるため外出保育の場所 については支障ないとの見解であつたが, 小規模保育拠点の運営者 には上記, 公園等の要望がある. また自治体としては道空間の重要 性について認識はなかったが, 運営者はこどもを連れての移動にあ たって道空間の整備を求めているという認識の差異が把握できた.

3）拠点内部での保育と外出保育の関わり 小規模保育拠点内部 での 1 日の生活の様子を図 1 に例示する. 外出保育の時間は 1 時間 〜 時間半程度だが, 外で見た電車や金魚の絵を拠点で描く, 採集 してきたドングリを使って工作をするなど, 外出保充での体験を拠

表3a ヒアリング結果一筧

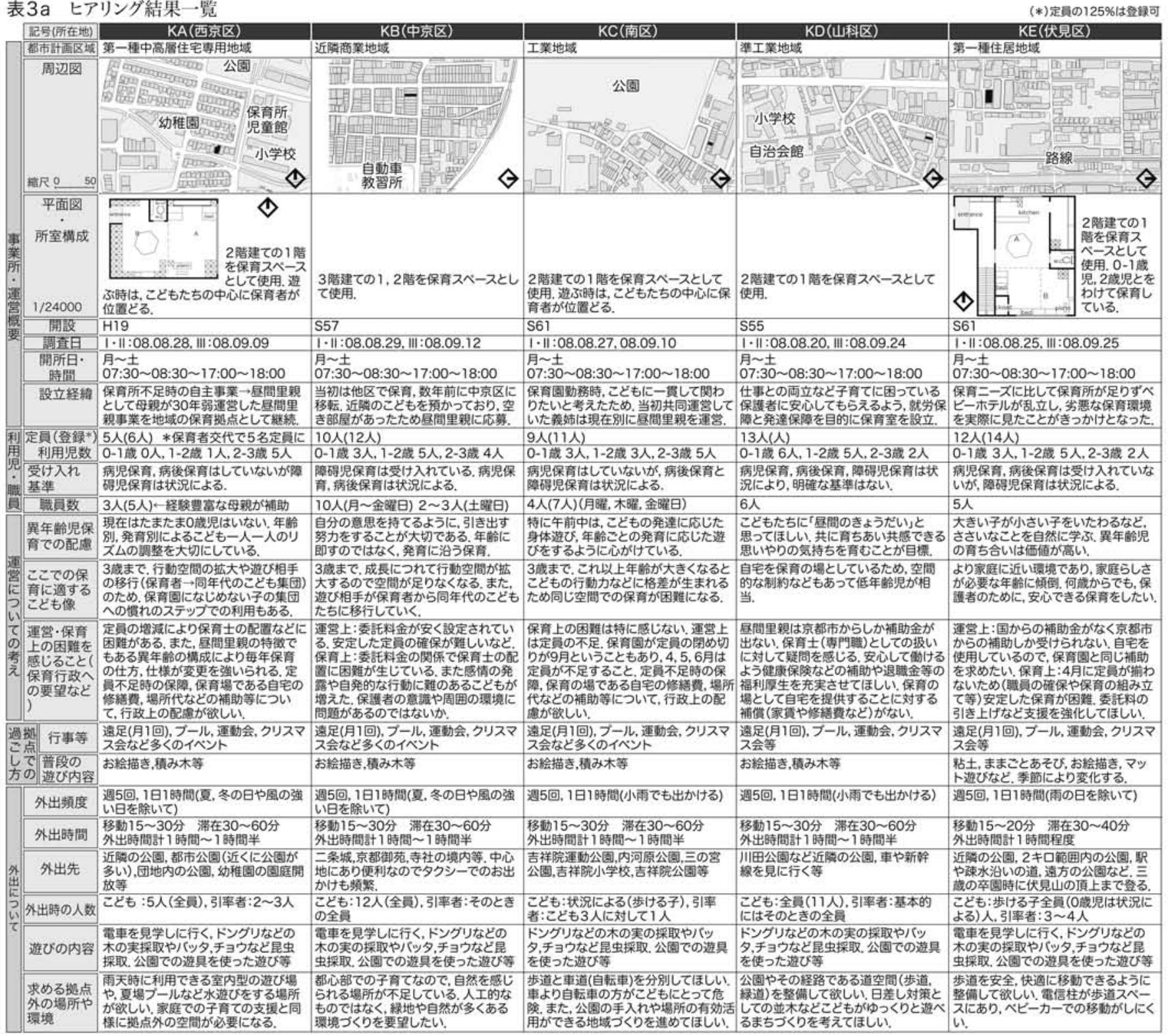


点内部での保育に取り入こんでこどもの活動内容が組み立てられて いる様子が観察できた。こうした保育内容は，こどもたちの多様な 体験や興味・関心の拡がりにつながっているといえ, 外出保育の充
実によって拠点内部での保育がより充実すると考える、またこうし た場面は昼間里親，保育所分園のいずれでも観察されたことから， 拠点の規模によらず外出保育に意義があるといえる.

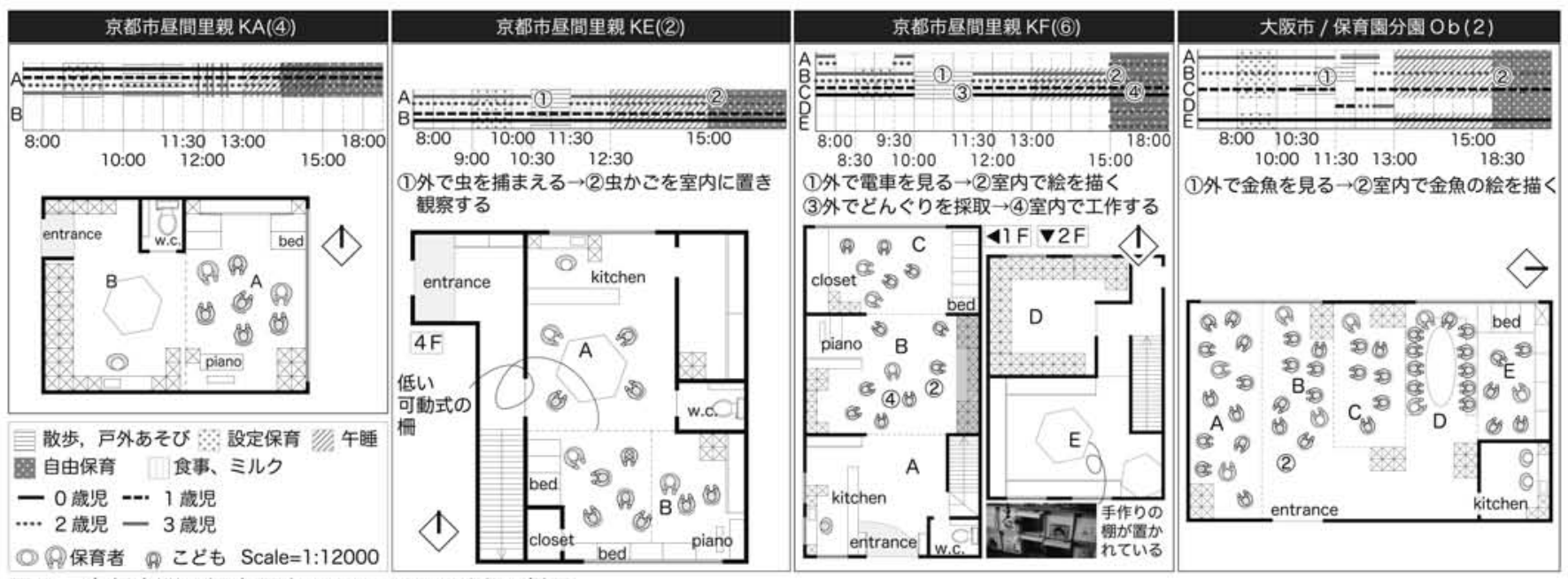

図 1 内部空間の観察調査による1日の活動の様子

表3b ヒアリング結果一覧

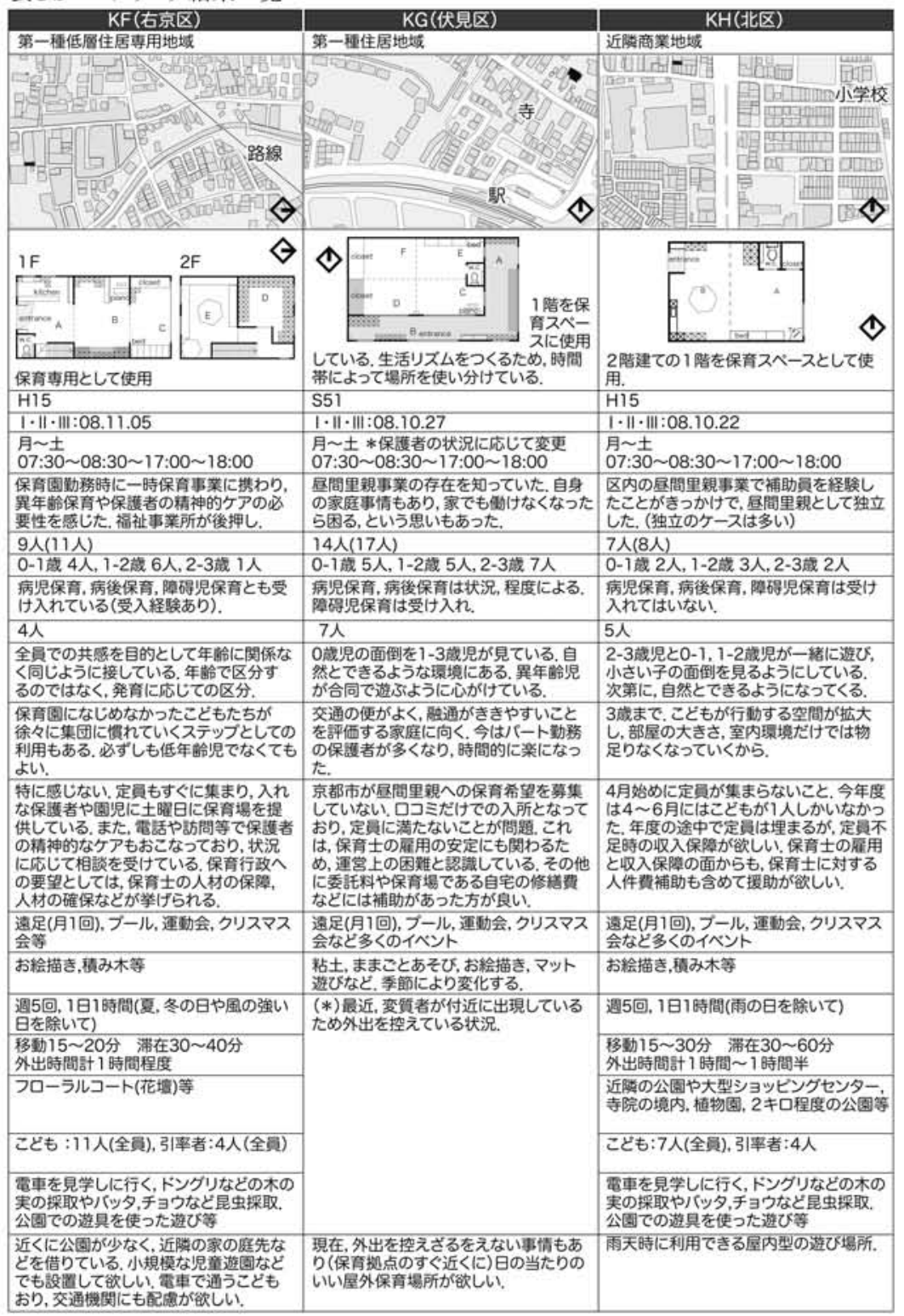

\begin{tabular}{|c|c|}
\hline OA(大陑市中央区) & OB(大郅市淀川区) \\
\hline 第二種住居地域 & 第二硾住居地域 \\
\hline 地下鉄 路線 & \\
\hline$y=$ & 一地下鉄 駅 \\
\hline 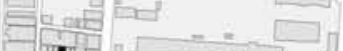 & \\
\hline 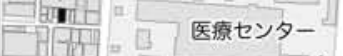 & 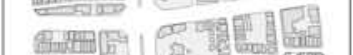 \\
\hline 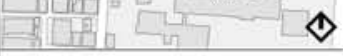 & 神社 E政 $\Leftrightarrow$ \\
\hline & 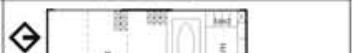 \\
\hline ルの1阹 & $\therefore$. \\
\hline 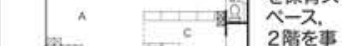 & $\begin{array}{l}\square \\
\text { の4腊を }\end{array}$ \\
\hline 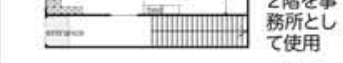 & ペース,2缕を事務所として使用, 同ヒル \\
\hline $\mathrm{H} 16$ & $\mathrm{H} 13$ \\
\hline $1 \cdot\|\cdot\| \|: 08.11 .20$ & $\mid \cdot\|\cdot\| \| 1: 08.11 .28$ \\
\hline $\begin{aligned} \text { 月 金 } & 07: 00 \sim 19: 00 \\
\text { 土 } & 08: 00 \sim 18: 00\end{aligned}$ & $\begin{aligned} \text { 月 金 } 07: 00 \sim 19: 00 \\
\pm \quad 08: 00 \sim 18: 00\end{aligned}$ \\
\hline 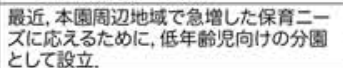 & 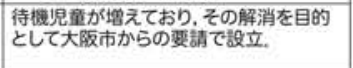 \\
\hline $30 人$ & 41 人 \\
\hline 0-1戴 6人, 1-2藏 11人, 2-3藏 13人 & 0藏 9人, 1歲 10人,2戴 11 人, 3蔵 11 人 \\
\hline 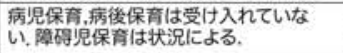 & 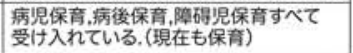 \\
\hline 14人 & $13 \hat{1}$ \\
\hline 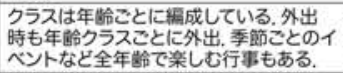 & 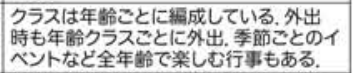 \\
\hline 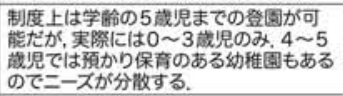 & 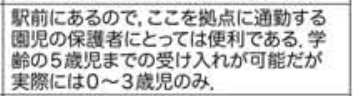 \\
\hline 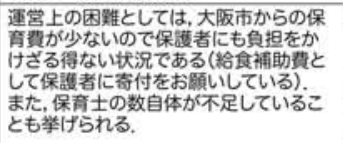 & 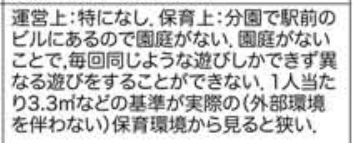 \\
\hline $\begin{array}{l}\text { 透足(年2回, 2-3才児),ブール, 運動会, } \\
\text { クリスマス会,ハロウンと多数 }\end{array}$ & $\begin{array}{l}\text { 遠足(年4.5回),ブール, 運動会, クリススマ } \\
\text { ス会,ハロウィンなと多くのイト }\end{array}$ \\
\hline お絵描き,頙み木,ねんと遊ひ等 & お絵描き,積み木,ねんと遊ひ等 \\
\hline 遇4回, 1日1時間(雨天を除いて) & 遵5回, 1日1時間(雨天を除いて) \\
\hline $\begin{array}{l}\text { 䔟動5 15分 滞在30分 } \\
\text { 外出時間計 1 時間程度 }\end{array}$ & $\begin{array}{l}\text { 䔟動 5 15公 滞在30分 } \\
\text { 外出時間計 } 1 \text { 時間程度 }\end{array}$ \\
\hline 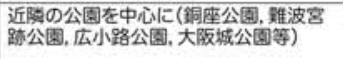 & 近瀿の公園 \\
\hline 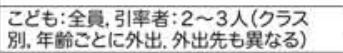 & $\begin{array}{l}\text { 己ども:全貝，引率者:全貣(クラス別, 年 } \\
\text { 踰こととに外出) }\end{array}$ \\
\hline $\begin{array}{l}\text { ドングリなどの木の実の採取やバッタ, } \\
\text { チョヴ昆虫採取,公園での遊具や妙 } \\
\text { 場を使つた遊ひ等 }\end{array}$ & $\begin{array}{l}\text { 電車を見学しに行く,ボール遊ひ、砂遊ひ， } \\
\text { フーブ,公園での遊具を使った遊ひ等 }\end{array}$ \\
\hline 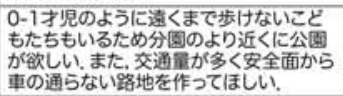 & 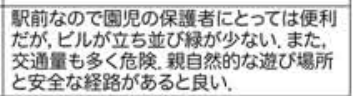 \\
\hline
\end{tabular}




\section{5。保育者による保育環境としての都市環境評価}

\section{1 都市環境評価の結果の整理}

調查が可能な昼間里親 7 例, 保育所分園 2 例で，キャプション評 洒調査（表 1 ）を実施した，以下，「満足／不満／父になる」の別を 【評価】，指摘されたことがらを【対象】，評価の理由を【理由】と呼
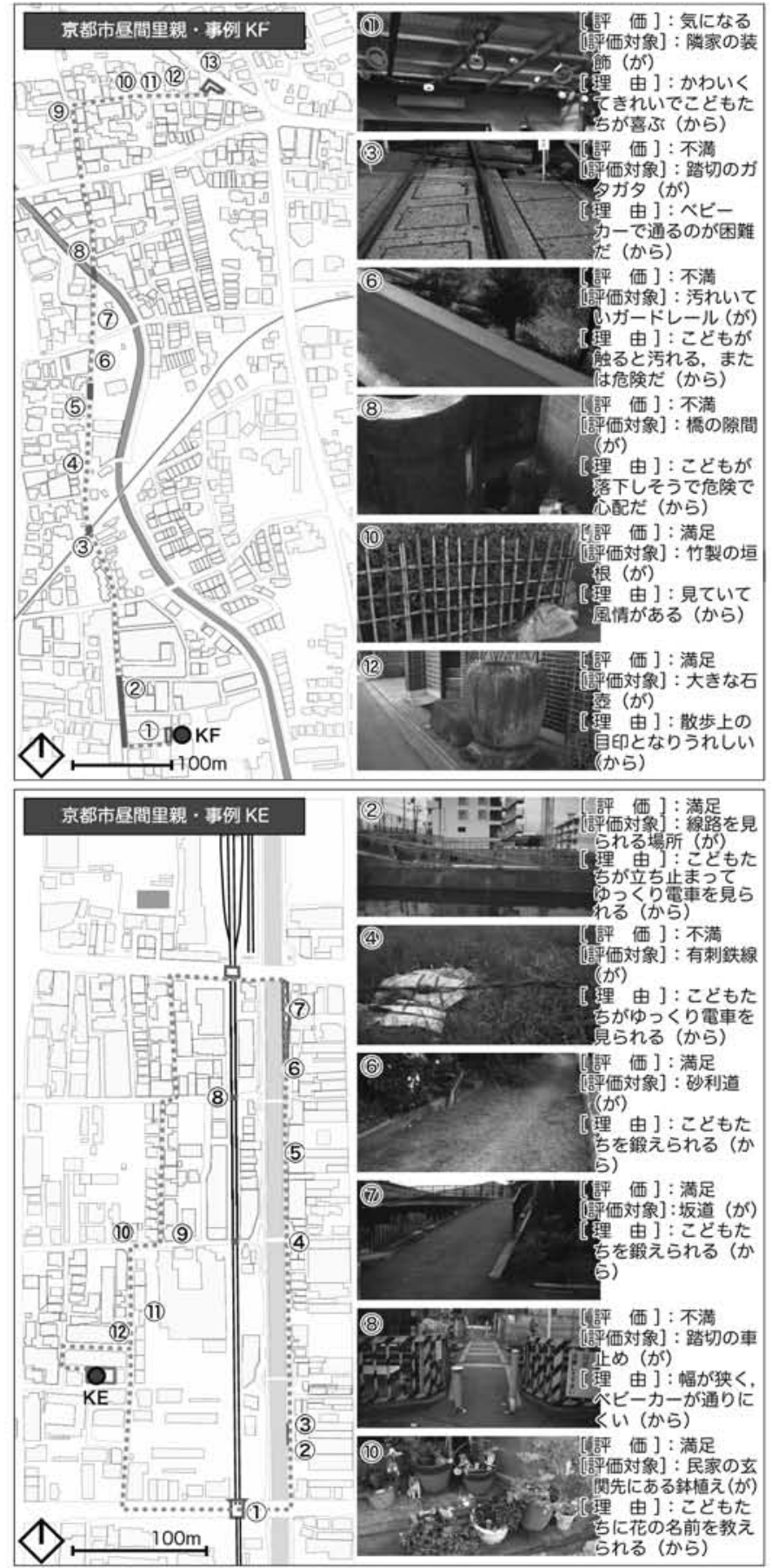

図2

保育者による都市環境評価の事例

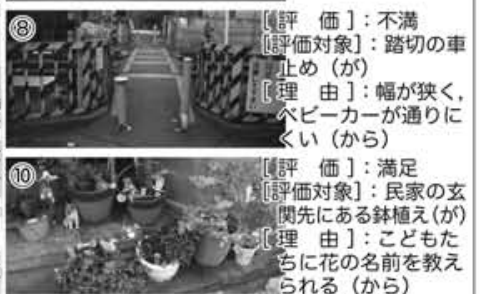

表4 評価の対象と理由
ぶ. 収集した評価の対象と理由を分解し,指摘があった場面を [滞在] と [移動]に分けた上で, 既往文献 ${ }^{13)}$ に即して類似した内容をまとめ,

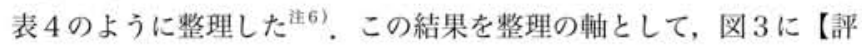
価・対象・理由】の全体像を示した，また，拠点ごとにみた［滞在］ [移動］場面別の【対象・理由】の内訳を図 4 に示す.
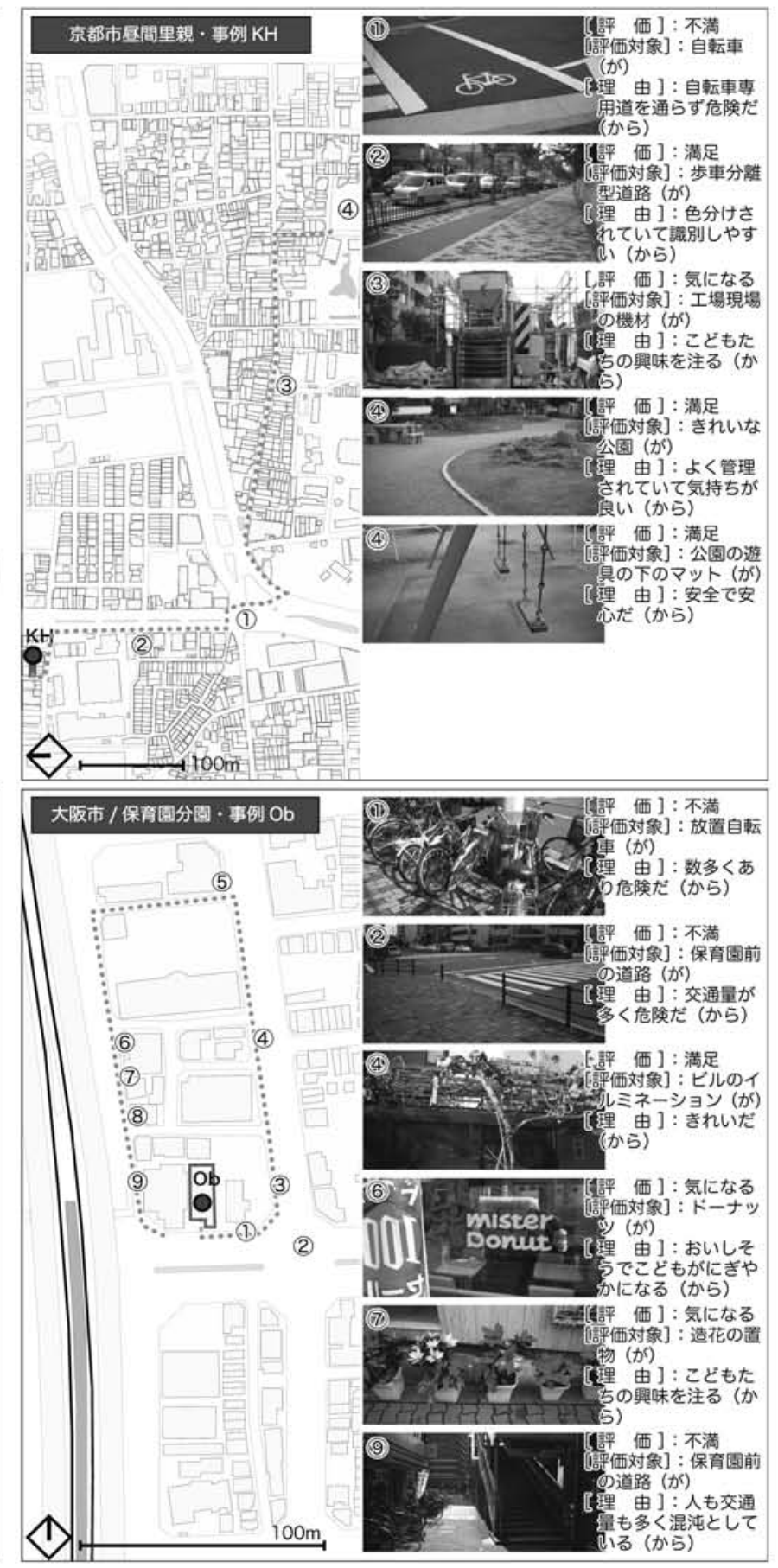


\section{2 評価の場面と【評価】}

指摘された場面の［滞留］と［移動］の別をみると（図 3 , 各右 上), 昼間里親 $(68.7 \%)$ では [移動] 場面での指摘割合が高く, 保育所分園ではさらに高い $(87.0 \%)$ ，いずれの拠点でも (図 4), [移 動］場面での指摘が [滞在］場面での指摘を上回った。表 3 の通り, 保育所分園での移動時間は昼間里親の半分程度で, 移動時間と滞在 時間の比率は同程度だが, 評価された場面では保育所分園の方がそ の割合が高い。つまり昼間里親に固有の特徵ではなく，拠点の規模 によらず都市環境を保育で利用する際に意識することがらの大半が [移動］場面にあり，その意識は移動にかかる時間によらず高いと指 摘できる. 外出保育での都市環境利用に際して地域環境への要望を 尋ねると（表 3)，[滞留］場面に分類される公園や屋内の遊び場所 への要望が多かった，しかし実際には，移動の空間でさまざな要 望や環境要素の意義が示唆された結果となった。

次に, 図 3 各左下に示した [滞留/移動] 場面別の評価内容を見 ると, 昼間里親では [滞留]場面よりも [移動］場面で [満足］評 価の割合が高いが, 保育所分園では [移動］場面で [不満］評価の 割合が高い，昼間里親の移動場面での［満足］評価は［道から見え るもの［ヒビューポイント］[道）に対する［保育資源としての価値］
を理由とするものが保育所分園よりも多い。このことから昼間里親 では，保育所分園よりも移動しながら移動自体（道）や道から見え るものを活かして積極的な保育がなされていると考える。この要因 として, 都市環境や外出保育児の人数規模の差異が考え得る. 都市

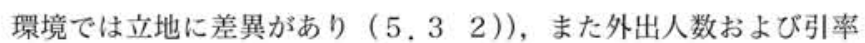
体制には，表 2,3 および観察より昼間里親では異年軨児 $5 \sim 10$ 人 (引率者: こども数 $=1: 2 \sim 3$ ), 保育所分園では同年齢児 10 人 程度 (引率者：こども数う1：5）と差異がある. 昼間里親では, 外出人数の規模が小さく引率者の割合が高いことでこどもの安全を 確保しつつ移動空間での保育を積極的に行え, 保育所分園での調査 結果との差異につながったのではないかと考える.

\section{3 評価の【対象】と【理由】}

1）評価の【理由】評価の【理由】は, 都市環境を保育の場とし て利用する際に発現する環境を評価する価値钼と捉えられる。昼間 里親での評価【理由】としては, [滞留] [移動]の場面とも [安全性］ が多い，[安全性］は [不満］評価の割合が高く，危険を感じながら 保育をしているとも，危険予測をしつつこどもたちの安全を確保し ようと努めているともいえる。逆に［保育資源としての価値］では [満足］評価の割合が高く, [興味·発話のきっかけ］となったり，[遊

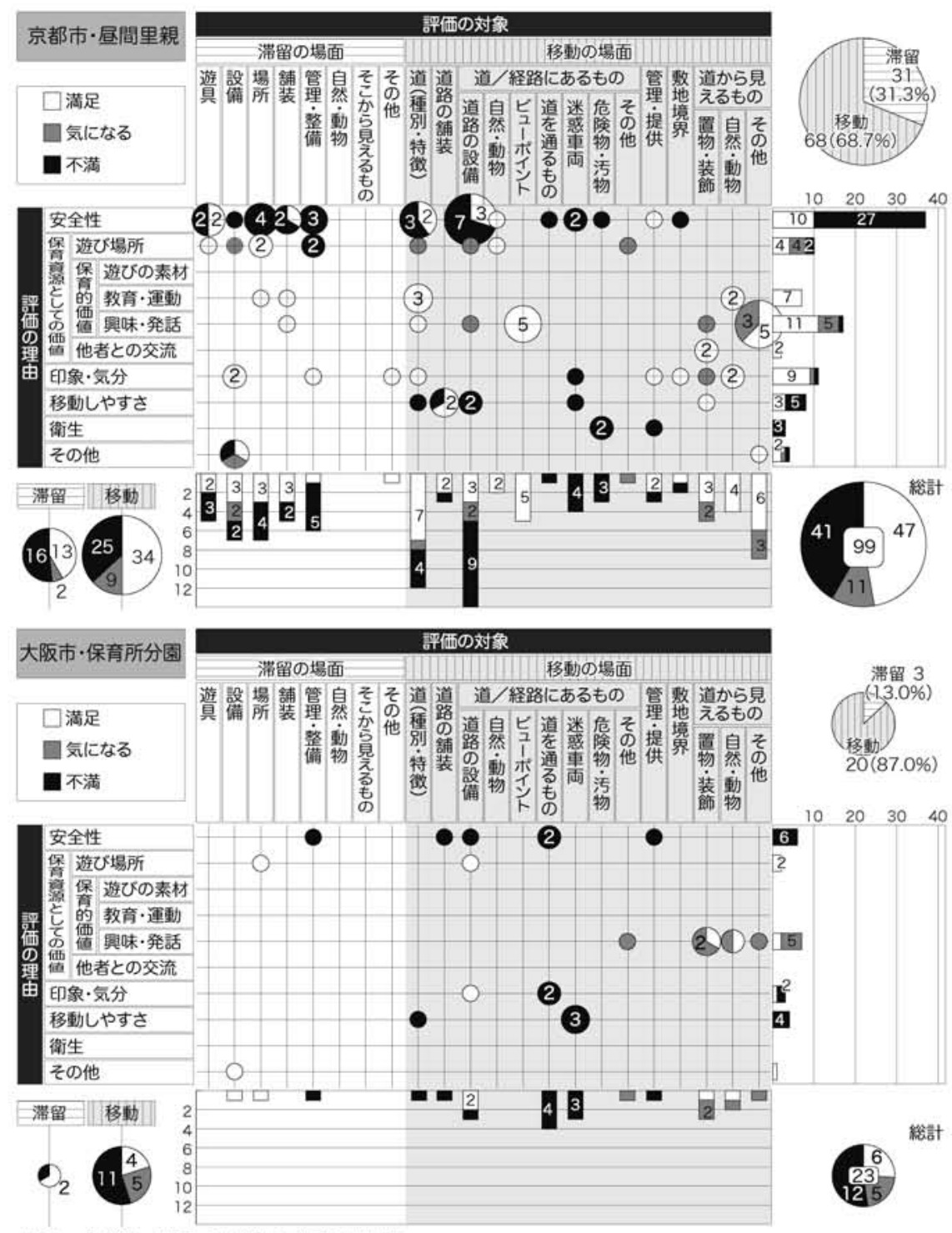

図3【評価·対象·理由】の内訳の比較

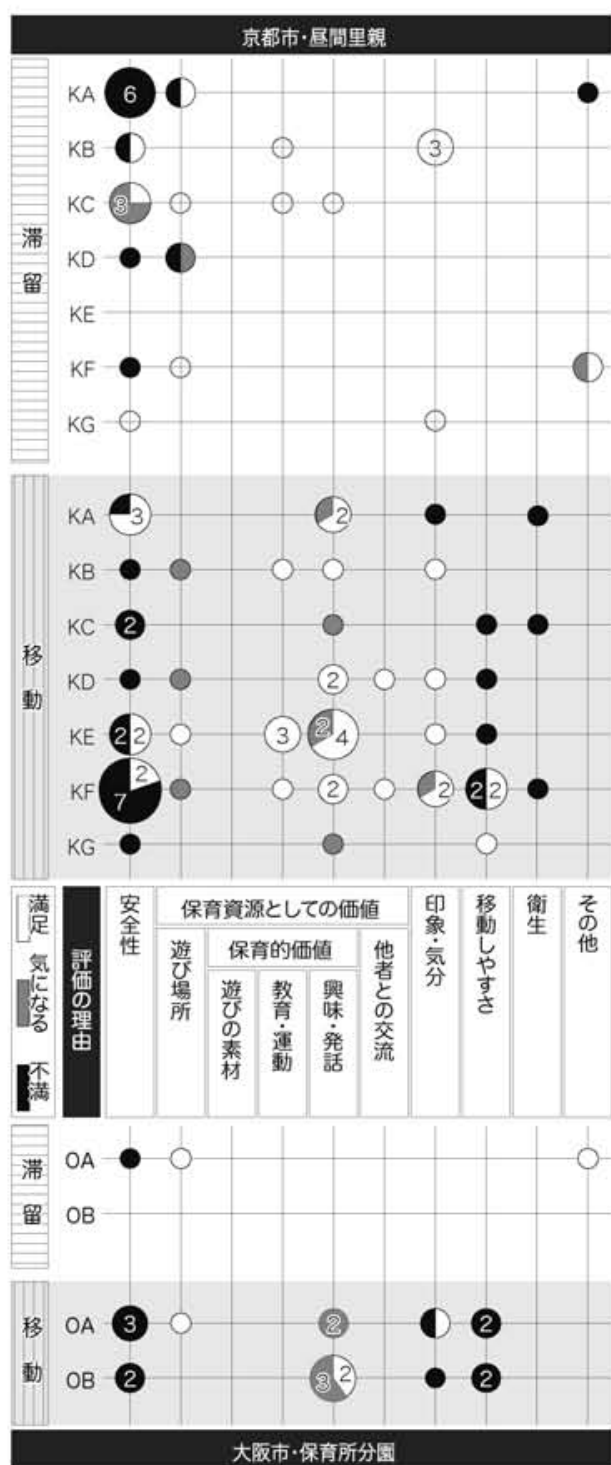

図4 拠点ごとの滞留/移動場面別の評価【理由】 
び場所としての価值を評価するコメントが比較的多かった．

[安全性] [興味・発話のきつかけ］[遊び場所］についてのコメン トが比較的多い傾向は保育所分園でも同様だが, 保育所分園ではこ れらの項目での [満足] 評価の割合は昼間里親よりも低く，[教育· 運動の機会］[他者との交流］といった【理由】は指摘がない.これ には, 調査対象とした保育所分園では年齢別クラスでの外出を行っ ており，2歳児クラスでは昼間里親よりも自分で動けるこどもの数 が多い状況での外出となるため, 外出保育時に遊びや運動を積極的 に楽しむあるいは活かす余裕が少ないのではないかと考えられ, 5.2 の, 引率体制と環境評価との関連の考察を補強する結果と考える.

2)【対象】×【理由】:安全性評価の理由として多く挙げられた[安 全性］は, 保育の場として都市環境を利用する際には重要な価值観 といえる. 評価理由に多かった［保育資源としての価値］とともに, その内容を表 4 に子細に示した. 昼間里親では保育所分園よりも[安 全性］に関するコメントの割合が高く, [滞留］の場面では［遊具］［場 所にについてこどもの利用への十分な配慮, 公園や公園の設えへの 十分な［管理・整備］について言及されている．また［移動］の場 面では特に [道路の設備]についての指摘が多く, 柶の老朽化や隙 間が大きいこと, 車両止めが車両進入に役立っている/いないこと, 排水满に蓋がつけられていること, などについて言及されている.

保育所分園では比較的指摘が多かった【対象】として, [道路の設 備］［道を通るもの］[迷惑車両］が挙げられる．保育所分園 2 拠点 では通行量の多さへの奬念はヒアリングでも指摘され（表 3 ), 歩 道などの整備環境よりも放置自転車や通行量に意識が向けられてい た.これには, 周辺環境が昼間里親よりも都心部に近いこと, また 移動時間が短く長距陮を移動しないことも関係していると考えられ る. 拠点の立地によって保育時の意識のありかが変わるといえ, 昼 間里親で見られた傾向は, 立地上の特性を受けた結果と考えられる. 3)【対象】×【理由】：保育素材としての価值保育の場として 都市環境を利用しながら, 保育の素材となる環境要素が指摘された ことは重要なことである. [保育資源としての価値]は, 昼間里親 と保育所分園のいずれも [移動］場面で多数指摘されている. なか でも［道から見えるもの］の指摘が多く, 昼間里親ではさらに[道 (種別や特徵)］［ビューポイント］での指摘も多かった，表 4 によっ てその内容を見ると, [道から見えるもの] では民家の庭先の人形や 鉢植え, 飲食店前の設えや電車などがこどもの興味・発話や知識を つけるきっかけとなっていることが指摘されている，また［道］で は坂道や砂利道が運動の機会や遊び場になっている, [ビューポイン
ト]では歩道橋や跨線橋など眺めるものがある滞留できる空間がこ どもたちの興味を引き立てる場所として指摘されている, 昼間里親 の [㯰物・装飾 $] \times$ [他者との交流 $]$ では, 家の前を通るこどもた ちのために季節の飾りや人形などを置いてくれているというコメン トがあり,こうした要素を介して地域住民との関係そのものが保育 の素材となっているともいえる.これらから, 都市環境のなかで様々 なことがらが保育の素材として見いだされていることがわかる．ま た道に隣接する數地の道に対する表情豊かな設えが保育素材となり うることもわかるが, こうした設えは保育の場としてのみならず広 い意味での地域の環境づくりにもつながるものである.

4)【評価】の対立＼cjkstart対象によっては, [満足] [不満]の評価がわ かれるものがあった，例えば坂道について，「こどもが飛び出してい きそうで (安全性)・危険だ」との意見がある一方で, 都市的な環境 でありこどもの身体能力の発達の機会が重要であるため,「こどもを 鍛えられるので（保育資源としての価值/教育・運動) - 良い」との 意見もあった. 同様のことがらが水辺 (遊び場所一安全性), 丘 (教育・ 運動一安全性)にもいえる.このように, 評価対象物によっては[安全] や［保育資源としての価值］などの理由で評価が対立する様子も把 握できた。こうした差異は, 保育者や保護者の考え方や, こどもの 年䑪構成, 周囲の交通量などや身体を動かす機会となる環境要素の 分布等の周辺状況などの複合的要因によると考えられる. 安全性の 側面からの判断のみで環境要素を簡単に排除するばかりでなく, 保 育拠点に求める保育理念や対象年㱓を勘案した場合には保育資源と しての価值を積極的に見いだせる可能性を踏まえる必要がある.

\section{4 移動/滞留と身体的干渉の有無による保育場面と評価}

昼間里親, 保育所分園とも, 隣接敷地の植栽や電車など [道から 見えるもの]への指摘が比較的多い.これらの【対象】には昼間里親, 保育所分園とも [不満] 評価がないことが特徵的である。これらの 環境要素は遊具や道など直接身体的な干渉を伴う【対象】とは質が 異なるため, 指摘があった保育場面での一定の領域への滞留の様子 (滞留, 移動中に立ち止まる, 移動) と, 身体的な干涉の有無（ない: 見る, ある: 体験する) によって指摘された内容を再整理し, 図 6 に示す.また, 評価の【理由】と保育場面の関係を図 7 に整理する. 図6, 図 7 から, [体験する] 場面では [不満] 評価の割合が高く, ことに[安全性］を理由とした評価の割合が高いことがわかる．身 体的な干涉が必要となるため, より怪我などの危険性が高く安全の 確保に意識が払われていることが確認できる.

また図 6 から,[見る］場面は [立ち止まる・見る］と［移動·見る］

表5 [安全性][保育資源としての価値]への指摘の詳細

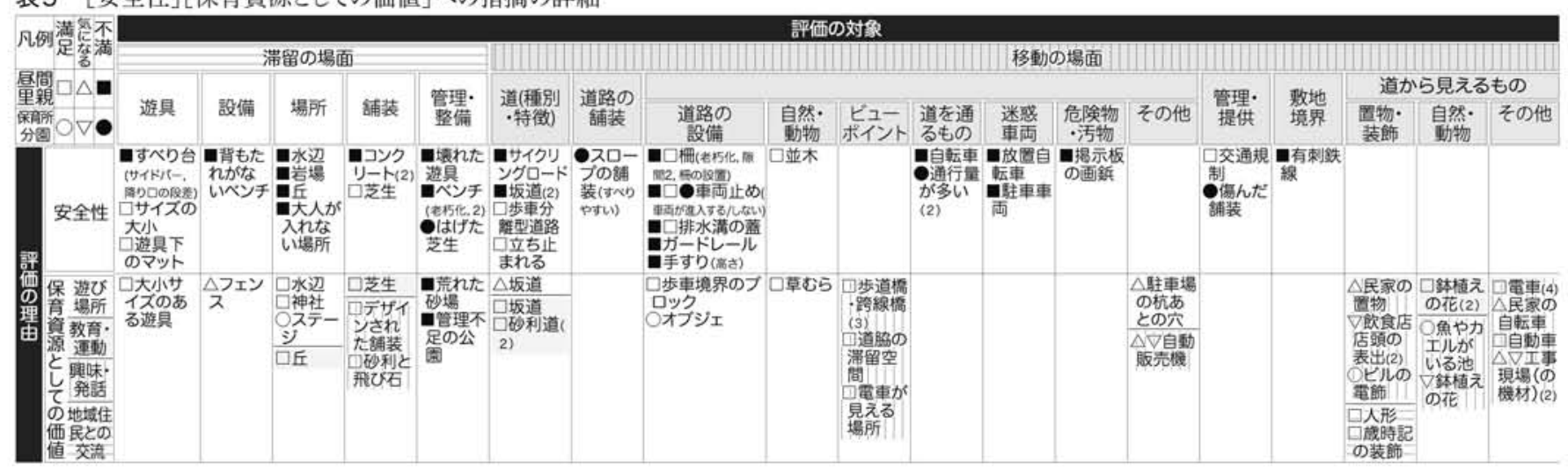


場面に分けられ，［立ち止まる・見る］場面では［不満］評価がない ことがわかる，この場面では評価の【理由】に[保育資源としての 価值］が多い（図 7)．［立ち止まる］場面でこのような特徵的な【評 価】の様子が見られる要因として，移動場面での［道から見えるも の）には興味や関心があった際に選択的に関わること, また [立ち
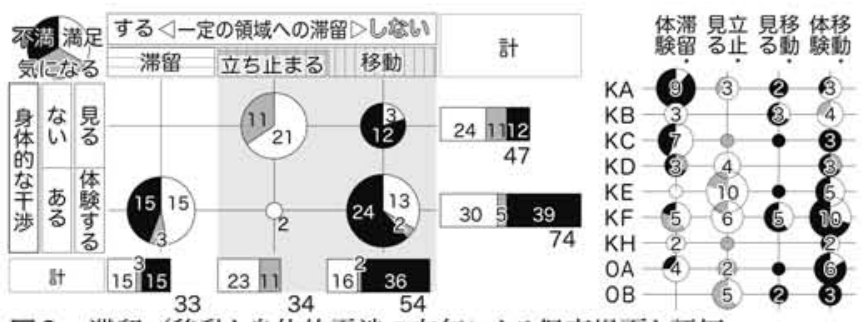

図6 滞留/移動と身体的干涉の有無による保充場面と評価

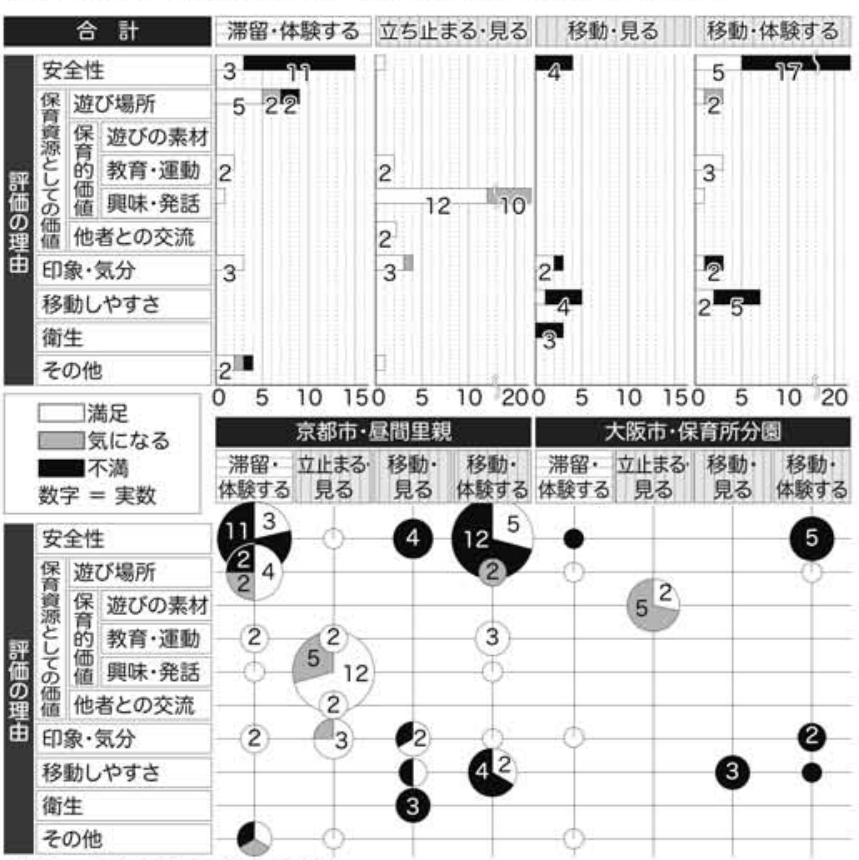

図7 保育場面と評価の理由
止まる]場面では安全面などとの兼ね合いでも立ち止まることがで きておりこどもの興味や関心にゆとりをもって応えられること, が 影響していると考える。こうした道空間に隣接する空間の設えや視 覚的な楽しみへの配虑，移動の途中に立ち止まれること，が移動場 面での保育を充実させると考えられる. 移動空間で立ち止まるため に, 指摘の内容から導出できる項目として, 通行量に比して道幅が 十分なことや歩道・歩行者スペースが整備されていること, 外出人 数に対して十分な滞留スペースがあること，などが挙げられる.

滞留/移動と身体的干涉の有無による保育場面での評価の傾向に は, 昼間里親と保育所分園での差異は見られず, 小規模保育拠点に 共通することがらと考えられる.しかし，[立ち止まる] 場面の数は, 昼間里親でより多く, 外出時の保育規模や引率体制 (5.2), 周辺環 境（5.3 2)）などが影響して, [立ち止まる] 場面が取れている点 は昼間里親での外出保育の特徴と考えられる.

\section{6. まとめ}

本稿では，公園などの都市の環境を保育の場とする小規模保育拠 点のうち主たる調査対象に京都市の昼間里親を, また比較分析の対 象に保育規模が異なる大阪市・保育所分園を選定し, 制度設計と運 営の実態を整理した．また, 保育者が拠点外の都市空間を保育の場 として利用する際の, 都市空間の環境要素への詊価をキャプション 評価法を用いて収集し, 保育の場としての都市環境に求められる配 虑について分析・考察した。本稿での知見と考察は以下に整理する.

いずれの制度とも, 今後とも拉充の方向にあり待機児童の緩和や 地域での子育て, 保育の場の多様性の確保などの観点で重要な役割 を担っていくと考えられる. しかし既往研究同様 ${ }^{2)}$ 制度設計上の問 題に保育者の労働条件や保育拠点の確保への財政支援などが挙げら れた。 また, 保育の場として必須の拠点外の都市空間については行 政と保育現場での認識に差異があり, 保育者からは公園などの屋外 で遊べ空間の整備や, 安全・快適な道空間への要望が聞かれた. これには, 小規模保育拠点の承認にあたって公園への距離や経路な

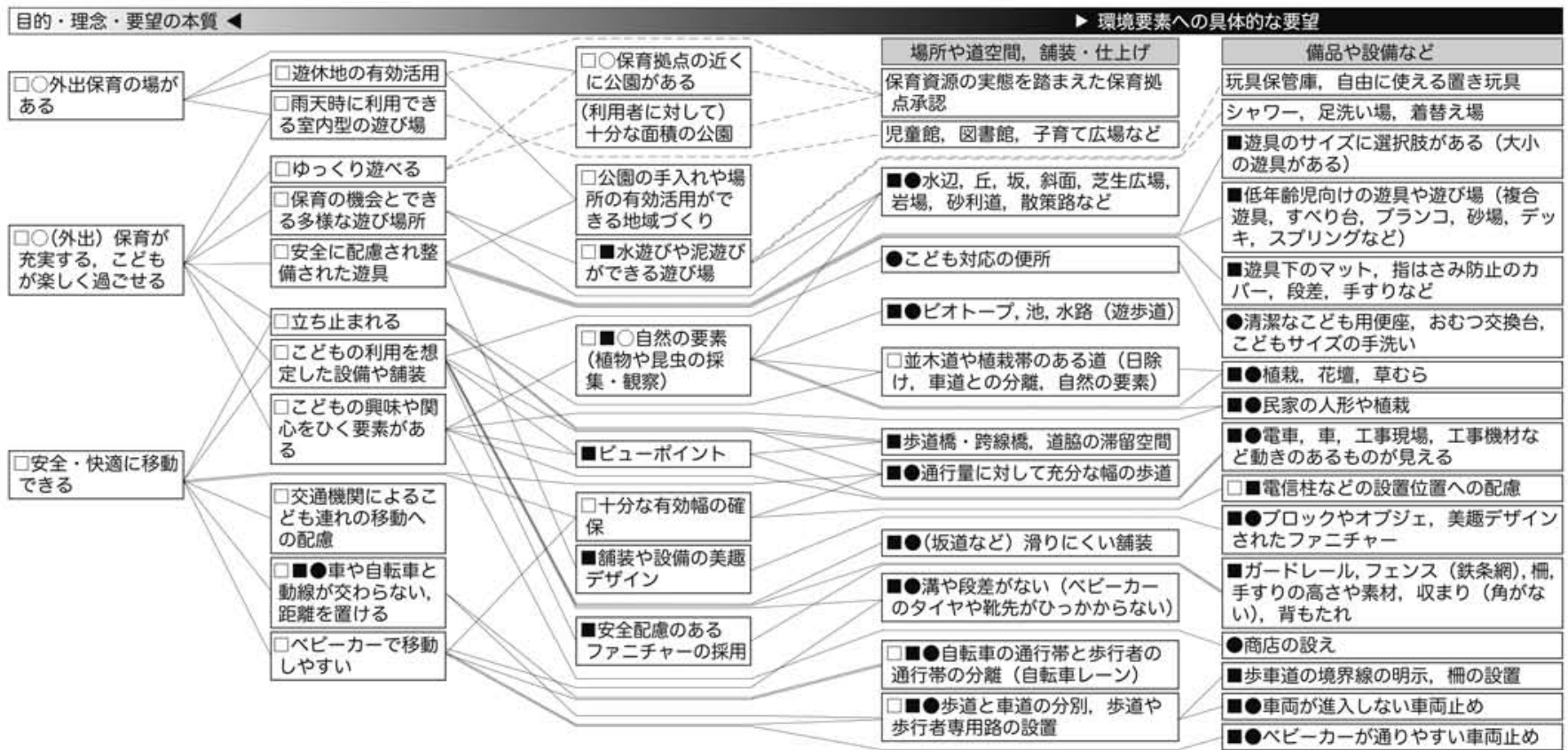

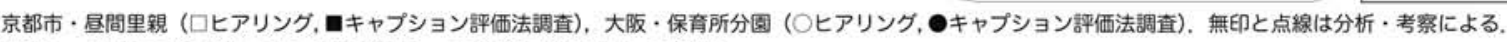

図8 保育の場としての都市環境への要望事項とその構造 
どの環境条件に規程がないことも一要因と考えられ，小規模保育拠 点による保育サービスの提供を推進する際には行政としても都市空 間の整備が必要となることを認識する必要性が示唆される.

都市環境評価では,いずれの拠点でも移動時間の長短によらず [移 動］場面での指摘が [滞在］場面を上回っており,外出保育では［移 動］場面でより多くのことがらが意識されることがわかった。 また 移動中に立ち止まれることで, こどもの興味や発話のきっかけとな る環境要素と関わりが生じていることもわかった，安全で，こども の興味や関心を引く要素がある移動の空間を整備することで外出保 育がょり充実すると考えられる，また一方で，例えば坂道など危険 性も伴うものの保育の機会として価值があると評価された環境要素 もあり, 安全性と保育资源としての価值は地域の環境条件や保育者 の人只配置などとの関係によっても影響を受けることがわかった.

また昼間里親と保育所分園では制度上, 拠点内外での保育時の集 団形成に差異があった，人数規模が大きい保育所分園では年羚別保 育だが，昼間里親ではいずれも異年秢混合保育で，保育者から家庭 的な保育やこども同土の育ち合いの点で評価されていた，外出保育 は拠点の規模によらず全拠点で日常的に取り入れ，その体験を拠点 内部での保育に活かす椂子が観察され, 拠点外の都市空間が保育の 場として重要な役割を担っていることが確認できた。 また昼間里親 では外出保育をより積極的に行っていた，これには都市環境の条件 の差異や, 外出保育の人数規模の差異などが影響していると考える.

以上の分析・考察による保育の場としての都市環境への要望とそ の構造は図 8 のように整理できる。本稿では, 保育の人数規模や周 囲の都市環境の状況によって都市環境への評価やそれを踏まえた保 㕕の内容が異なることが示された，小規模保育拠点制度は自治体に よって保育の人数規模, 集団形成などに差異があり本稿の成果が一 概に当てはまらない場合もある，今後，対象事例を増して知見の一 般化をはかり，また地域や制度の個別性に応じた望ましい制度と都 市環境づくりのあり方への知見を得ることをさらなる課題とする.

謝辞本研究は, 財団法人旭硝子財団による研究助成を受けて実 施しました。調査にあたり, 京都市, 大阪市, 保育拠点の皆様に ご協力をいただきました。ここに記して謝意を表します。

\section{注}

注 1 ) 自治体独自の認可保育所に準ずる保育施設である東京都認証保育所,

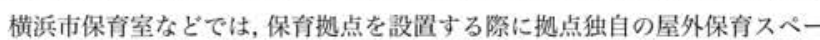
スをもつ必要はないが, 公園などの“屋外遊技場に代わる屋外保育スペース” が近隣にあることが認証条件にある，ただし，その距崔や時間距離，屋外 遊技場の大きさについての規定はなく各運営者の判断にゆだねられている.

注 2 ) ここでの都市構造とは, 都市内・都市間の移動手段, 就業地域と居住 地域の位阅関係およぴ時間距崔（職住構造），保育所等の保育サーピス拠点 の数量を立地, を指す。

注 3 ）キャブション評価法は, 評価者が日常的に体験している環境のなかか ら「いい/悪い/気になる」事物を抽出してその評洒理由を述へることで 環境のなかで意䜾される事物や環境評価の理由を理解する手法であり，保 育者が保育の場としての外部環境のなかで「どのような事柄を意識し」「ど のように評価しているのか」を把握するために適切な手法であると考えた。

注 4 ) 京都市の KA, KBについては1ルートに同行，2ルートは闑き取り後 に該当筒所を調查員が訪れ，写真攝影と周辺状況の記録を行った。なお，

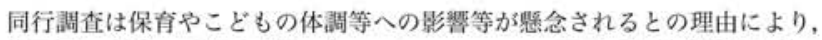
複数回の実施が困難な事例が多かった。 KG では, 調查時点当時外出を控え ていたため調查 I・IIのみとした.
注 5 ) 昼間里親運営者の経験年数に応じ， 5 名ないし 10 名以内と定められる. 注6）例えばKF の場面(2)では, “【対象：踏切の段差】が,【理由:ベピーカー で通りにくい】ので【評価：不満】”と読み取れる。また KEの場面(2のよ うに“電車 $($ が 興味や発話のきつかけとなる (ので) 満足”, “電車が見 えること (が) 興味や発話のきっかけとなる (ので) 満足”, “(歩行者専用 道のため車などを父にせずに）道に立ち止まれること（が）ゆっくりでき る(ので) 満足” と, 複数の評洒対象と理由に分解される場合もあった。 KE (2)では, 電車というこどもの興味をひくものを, 安全に立ち止まって見 ることができるということが評価されており，その評価理由は［保命資源 としての価佸（興味・発話のきっかけ）と［安全性］に整理できる。

\section{参考文献}

1) 厚生労働省：“社会保障窑議会少子化対策特別部会第 1 次報告 一次世代 育成支援のための新たな制度体系の設計に向けてー”, 〈http://www.mhlw. go.jp/shingi/2009/02/dl/s0224-9c.pdf>, 2009.02.24, 参照 2009.08.06

2) 伊志领美津子, 輥田紋子, 小野壽美, 田島恵子, 江口玲子 : 家庭型保育 に関する研究 $I \sim V I$, 日本保育学会大会研究睔文集，(51）pp.834-837 1998.04, (52) pp.772-775 1999.04, (53) pp.816-817 2000.04, (54) pp.762-763 2001.04

3）松橋圭子, 大原一興, 藤岡泰寛, 三輪律江, 谷口新 : 地域における親子 の居場所選択からみた子亩て支援施設のあり方に関する研究 東京都三鷹 市における外出調查より, 日本建築学会計画系論文集, No.600, pp.25$32,2006.02$

4) 社会福祉法人四恩学園 (北浦かほる編)：夜間保育園の保育環境整借に向 けて 調査報告書, 2001

5）赤木徽也, 他：駅型保育園における環境整借条件に関する基硕的研究 その $1 \sim 5$, 日本建築学会大会学術講演梗概集 E-1 分冊, pp.517-520 2004.07, pp.169-174 2003.07

6) 松橋圭子, 三輪律江, 谷口新, 他 : 保分施設における園外活動の実態か らみた地域資源の使われ方についてー横浜市を対象としたアンケート調査 より, 日本建築学会大会学術講演梗摡集 E-1 分冊, pp.195-196, 2008.07

7 ) 谷口新, 三輪律江, 松橋圭子, 他 : 保育施設の園庭の有無と園外活動と しての公園利用に関する考察, 日本建築学会大会学術講演梗概集 E-1 分冊, pp.197-198, 2008.07

8 ) 田中稻子, 三輪律江, 松橋圭子, 他 : 横浜市における駅前保有施設の園 外活動の場としての街区公園利用とその評価に関する研究, 都市計画論文 集 44-3, pp.373-378, 2009.10

9 ）小池孝子, 定行まり子：都市部における保亩施設の屋外保市環境につい て 東京都区部における複合型保育所の施設環境に関する研究 その 2 , 日本建筑学会計画系綸文集 NO.628 pp.1197-1204 2008.06

10）古賀管章, 高明彦, 宗方淳, 他：キャプション評洒法による市民参加型 景観調查 都市景钼の認知と評価の構造に関する研究 その 1 , 日本建築 学会郭画系脸文集 NO.517, pp.79-84 1999.3

11）小島隆矢, 古賀誉章, 宗方淳, 平手小太郎:多変量解析を用いたキャブショ ン評価法データの分析 都市景钼の認知と評価の構造に関する研究 その 2, 日本建筑学会計画系綸文集 NO.560 pp.51-58 2002.10

12）趙晟恩, 佐藤栄治, 山田あすか, 佐藤将之, 西出和彦: 多摩二ュータウ ンにおける子育て期の親による都市環境の利用と評価子育て環境とし ての都市環境垀価に関する研究 その 1 , 日本建筑学会計画系脸文集 NO.643, pp.2003-1012, 2009.09

13）山田あすか, 佐藤栄治, 說岐亮: 小規模保育拠点運営者による子育て 環境としての都市環境評価に関する研究 - 世田谷区・家庭保育福祉員と 京都市・昼間里親を対象として一, 日本都市計画学会 都市計画論文集 No.44-3, pp.175-180, 2009.10

14） NPO 法人家庭的保育全国連絡協議会, 〈http://www.familyhoiku.org/>, 参照 2010.03 .08

15）大阪市，こども青少年局子育て支援部保有指導担当，“認可外保育 施設最新立ち入り調查結果”, <http://www.city.osaka.lg.jp/kodomo/ page/0000027886.html>, 参照 2010.03.09

16）厚生労働省㕍用均等・児童家庭局, “家庭的保育事業の実施について”, $<$ https://www.k-jobnet.jp/?action=common_download_main\&upload_ id $=312>，$ 参照 2010.03.09 